УДК 635.655:631.526.3

(C) 2018

Білявська Л. Г., кандидат сільськогосподарських наук,

Васецький Ю. П., аспірант,

Пилипенко О. В., здобувач,

Білявський Ю. В., кандидат біологічних наук,

Діянова А. О., фахівець II категорії

Полтавська державна аграрна академія

\title{
ВИСОКОАДАПТИВНИЙ СОРТ СОЇ АКВАМАРИН
}

\section{Рецензент - доктор сільськогосподарських наук, професор В. М. Писаренко}

Показано ијіність білкової культури сої, універсальність ї̈ використання, генетичний потенціал, вимоги споживача та переробника. Розглядаються шляхи та перспективи формування сортових ресурсів сої в Украӥні. До державного Реєстру сортів рослин, придатних для поширення в Украӥні, занесено значну кількість різноманітних сортів сої. Відмічається зростання частки скоростиглих сортів. Відповідно до сучасних вимог, сорт сої повинен бути високоврожайним, адаптивним, із високим генетичним потенціалом та мати відповідний рівень захисту рослин від біотичних та абіотичних факторів середовища. Базуючись на довготривалому практичному досвіді в селекції сої, у полтавському селекцентрі створено сорти з підвищеним базовим потенціалом. Серед них особливу иінність має сорт Аквамарин, занесений до Державного реєстру сортів рослин, придатних для поширення в Україні в 2013 рочі. Представлено окремі вимоги до елементів агротехніки.

Ключові слова: соя, сорт, селекиія, характеристика сорту, господарчі ознаки, адаптивність, врожайність.

Постановка проблеми. Соя - цінна олійна $\mathrm{i}$ зернова культура світового землеробства. Широке поширення сої на всіх континентах і в багатьох країнах світу обумовлено високими якісними показниками зерна, порівняно невисокою енергомісткістю іiі вирощування, універсальністю використання (харчовий, кормовий, технічний, медичний) $[1,2]$. В іï насінні міститься 38 $42 \%$ білка, 18-23\% жиру, 25-30\% вуглеводів, зокрема розчинних цукрів - 9-12\% маси насіння, крохмалю - 3-9 \%, клітковини - 3-7 \%, близько $2 \%$ фосфатидів, 4-7 \% неорганічних речовин, мікроелементів, ферментів та вітамінів.

На сучасному етапі розвитку сільського господарства сорт залишається не тільки засобом збільшення урожайності, але і стає фактором, без якого неможливо реалізувати накопичений генетичний потенціал, задовольнити вимоги споживача та переробника [3]. Національні сортові ресурси України є основою продовольчої безпеки держави. За рахунок використання нових високоврожайних сортів сої стає можливим значно збільшити виробництво сільськогосподарської продукції. Проте і досі виробникам сої важко підібрати сорт, який відповідає комплексу вимог і може щорічно давати стабільно високі врожаї.

Аналіз основних досліджень і публікацій, у яких започатковано розв'язання проблеми. На початок 2016 року до державного Реєстру сортів рослин, придатних для поширення в Україні, занесено 170 сортів сої [4]. У порівнянні з 2000 роком, кількість сортів вітчизняної селекції зросла у 3 рази, в тої час як кількість сортів іноземної селекції - в 11 разів. Значно зросла частка скоростиглих сортів.

Сучасні сорти характеризуються вузькою екологічною пристосованістю та придатні для вирощування у грунтово-кліматичних умовах певної географічної широти [5-6]. В інших зонах соєсіяння у сортів можливі зміни вегетаційного періоду, продуктивності, хімічного складу насіння, стійкості щодо шкідливих організмів, впливу стресів. В Україні швидко збільшуються посівні площі під соєю. Країна вийшла на перше місце в Європі 3 площ та валового виробництва зерна сої.

Тому створені високоврожайні й адаптивні сорти, що мають високий генетичний потенціал $\mathrm{i}$ відповідний рівень захисту рослин від біотичних i абіотичних факторів середовища, повинні зайняти свій регіон вирощування. Ефективне використання сортів можливе лише за оптимальних грунтово-кліматичних умов. Базуючись на довготривалому практичному досвіді в селекції сої, у полтавському селекцентрі виведено сорти 3 підвищеним базовим потенціалом. Серед них найвищу цінність становить сорт Аквамарин.

Головною метою наших досліджень було створення високоврожайних сортів сої для зон Лісостепу та Степу України.

Методика проведення досліджень. Для створення сортів і вивчення їх у Полтавській, 


\section{СІЛЬСЬКЕ ГОСПОДАРСТВО. РОСЛИННИЦТВО}

Харківській, Сумській, Дніпропетровській областях використані джерела адаптивності до лімітуючих факторів (шляхом гібридизації) 3 метою оцінки на посухостійкість, стійкість проти хвороб, до кислих грунтів і комплексу кліматичних чинників. Закладка польових i лабораторнопольових дослідів і фенологічні спостереження проводили відповідно до Державних стандартів України та методичних вказівок Державної комісії із сортовипробування. Характеристику морфо-біологічних ознак протягом вегетації одержували згідно з уніфікованим класифікатором роду Glycine [7].

Результати досліджень. Багаторічні спостереження та оцінка селекційного матеріалу дали змогу створити сорти з підвищеним базовим потенціалом. Серед них найвищу цінність становить сорт ранньостиглої групи - Аквамарин. Надаємо його коротку морфо-біологічну характеристику. Сорт пройшов державне сортовипробування в 2013-2014 роках і з 2015 року занесений до Державного реєстру сортів рослин, придатних для поширення в Україні.

Морфологія. Тип росту - проміжний. Рослина має напівстиснутий кущ висотою 71-90 сантиметрів (рис. 1). Стебло середньої товщини - 7,012,0 мм, стійке до вилягання. Забарвлення опушення - сіре. Кількість міжвузлів - 10-12 штук. Кількість гілок - 1-3, кут їх відгалуження 20$30^{\circ}$. Висота прикріплення нижнього бобу -15 сантиметрів. Коренева система добре розвинена.

Листки трійчасті, середніх розмірів. Суцвіття - багатоквіткова китиця, по 5-7 квіток. Забарвлення віночка квітки - біле. Боби середньої довжини, слабко зігнуті з гострим кінчиком, 32 2-3 насінинами, світлі, з рідким опушенням. Насіння

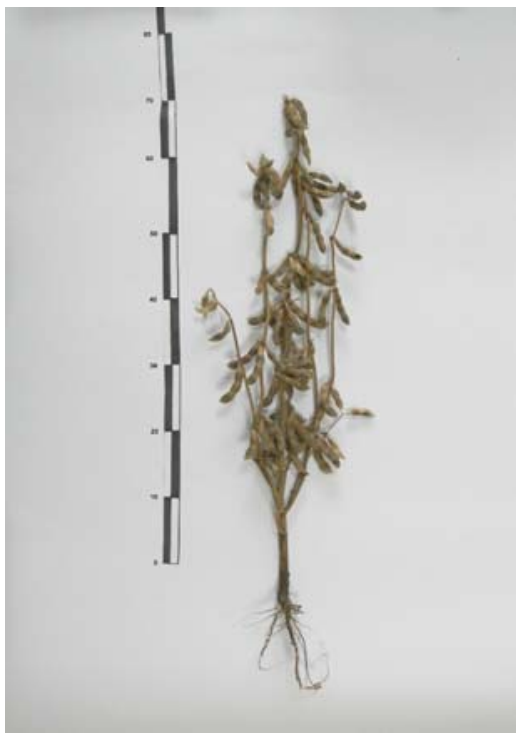

Рис. 1. Загальний вигляд рослини сорту середнє (0,6 х 0,4 см), округло-овальне (рис. 2). Основне забарвлення оболонки - жовте. Насіннєвий рубчик - рудий з вічком. Маса 1000 насінин - 170-180 грам.

Вміст білка в насінні - $43 \%$, жиру - $22 \%$.

Біологічні особливості. Гарантований попередник для озимих культур. У ньому вдало поєднані висока продуктивність та якість насіння. Тривалість періоду від появи сходів до цвітіння - 35-40 діб. У різних за географічною широтою регіонах має стабільний вегетаційний період тривалістю до 100 діб. Потенційна урожайність зерна в умовах Степу та Лісостепу України 3,0-3,2 т/га.

Має нейтральну фотоперіодичну реакцію, що забезпечує стабільний вегетаційний період у різних кліматичних зонах. На момент достигання швидко досягає кондиційної вологості і не потребує досушування (рис. 3).

Сорт зернового типу використання. Стійкість проти вилягання і розтріскування бобів за тривалого перестою висока. Сорт стійкий проти бактеріальних і вірусних хвороб, шкідниками пошкоджується слабо. Агротехніка сорту Аквамарин - загальноприйнята для умов України. Норма висіву - 600-700 тис. штук схожих насінин на гектар. Сорт добре реагує на внесення добрив $\mathrm{i}$ передпосівну інокуляцію насіння біопрепаратами. Глибина загортання насіння - 4-6 см. Характеризується підвищеною адаптаційною здатністю до несприятливих умов вирощування, в т.ч. до вирощування на кислих грунтах ( $\mathrm{pH} 4,5-5,5)$. Сорт рекомендований для вирощування на зерно у Степу та Лісостепу України. Вирівняність насіння - $95 \%$.

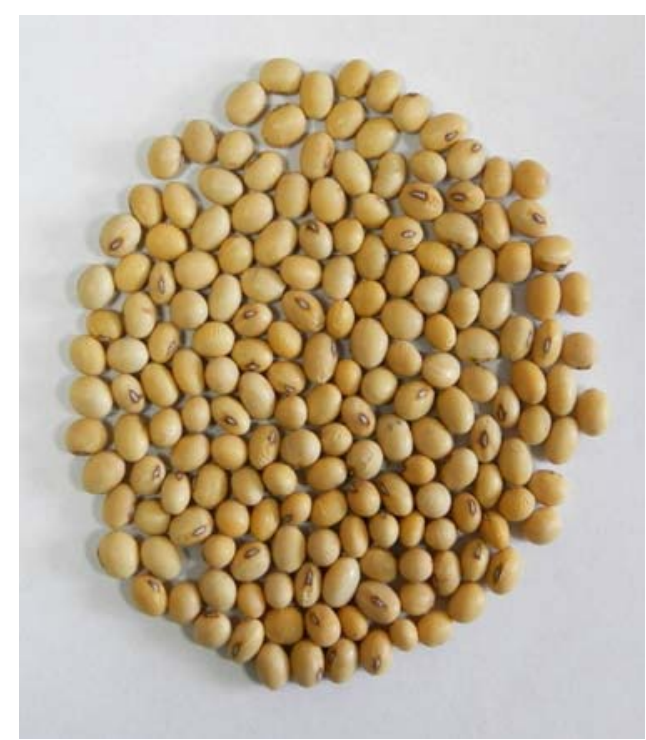

Рис. 2. Насіння сорту Аквамарин 


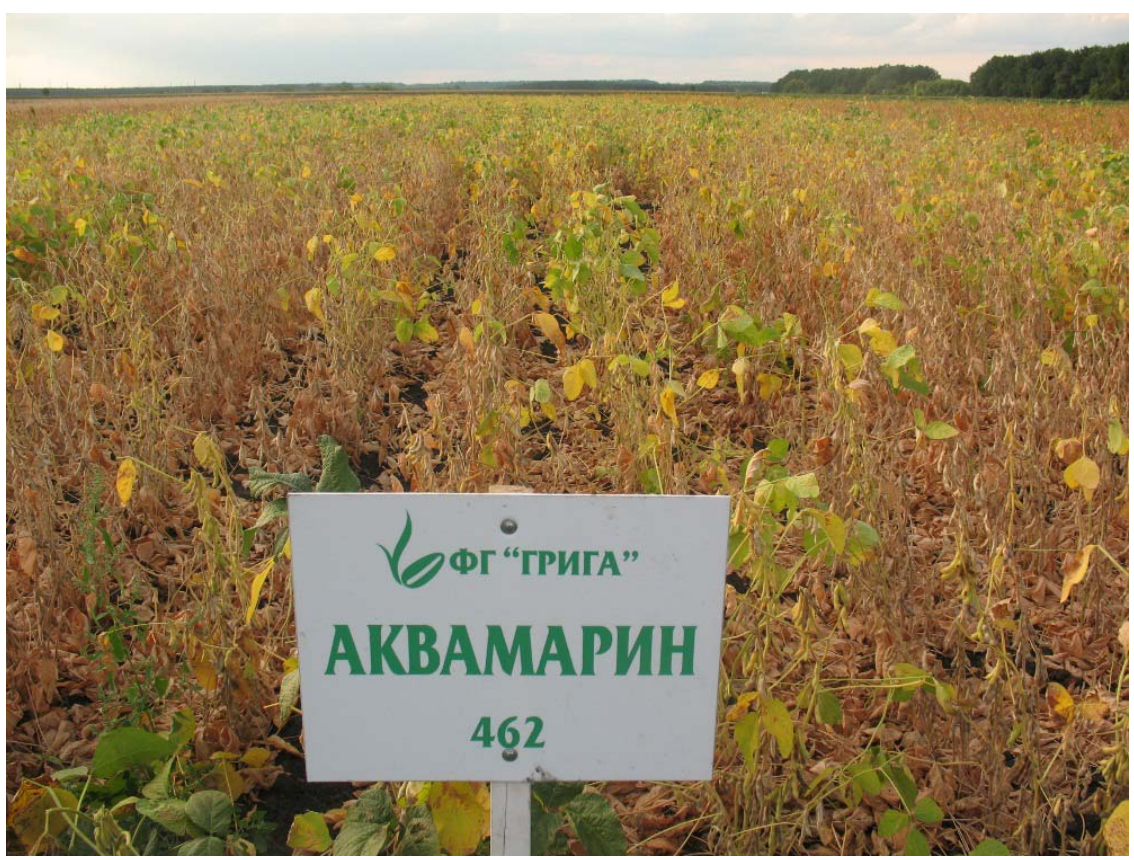

Рис. 3. Загальний вигляд посіву сорту сої Аквамарин

Висновок. Сорт - один із важливих засобів підвищення продуктивності культури. Вдало підібраний господарством сорт значно компенсує негативний вплив на очікуваний урожай грунтово-кліматичних умов вирощування, використання недосконалої техніки, дефіцит мінера-

\section{БІБЛІОГРАФІЯ}

1. Бабич А. О. Кормові і білкові ресурси світу / А. О. Бабич. - К. : Аграрна наука, 1996. - 822 с.

2. Білявська Л. Г. Особливості насінництва сортів сої селекції ПДАА / Л. Г. Білявська, О. В. Пилипенко, А. О. Діянова // Конкурентноспроможне насіння - стабільний урожай : тези міжнар. наук.-практ. конф., (30-31 січня 2013 р.). Полтава : ПДАА. - 2013. - С. 55-56.

3. Білявська Л. Г. Високоадаптивні сорти сої Полтавської селекції / Л. Г. Білявська, О.В.Пилипенко, А. О. Діянова // Посібник Українського хлібороба. - Мін. АПК. - Інститут рослинництва ім. Юр'єва. - 2013. - Т. 2. - С. 150-151.

4. Державний реєстр сортів рослин, придатних льних добрив і засобів захисту рослин тощо. Рекомендований для вирощування у Степу та Лісостепу України адаптивний сорт сої Аквамарин має значний потенціал і високу стабільність урожаю по роках.

для поширення в Україні в 2016 році [Електронний pecypc]. - Режим доступу : http://vet.gov.ua/sites/default/files/Reestr\%2006042 016.pdf.

5. Beliavskaya L. The results of study of ecological stability and plasticity of Ukrainian soybean varieties. - Annals of Agrarian Science. - Volume 15, 1ssue 2, June 2017. - Pages 247-251.

6. Сичкарь В.И. Селекция сои на адаптивность к факторам внешней среды : автореф. докт. дис. - Одесса, 1990. - 36 с.

7. Широкий уніфікований классификатор рода Glycine max (L.) Merr. - X. : Магда LTD, 2004. $37 \mathrm{c}$. 